Catholics and Contraception 


\title{
VOLUMES IN THE SERIES
}

\section{Cushwa Center Studies of Catholicism in Twentieth-Century America}

edited by R. Scott Appleby, University of Notre Dame

\begin{abstract}
Horizons of the Sacred: Mexican Traditions in U.S. Catholicism edited by Timothy Matovina and Gary Riebe-Estrella, SVD
\end{abstract}

Habits of Devotion: Catholic Religious Practice in Twentieth-Century America edited by James M. O'Toole

Ballots and Bibles: Ethnic Politics and the Catholic Church in Providence by Evelyn Savidge Sterne

Claiming the City: Politics, Faith, and the Power of Place in St. Paul by Mary Lethert Wingerd 
LESLIE WOODCOCK TENTLER

\section{Catholics and Contraception An American History}

CORNELL UNIVERSITY PRESS

Ithaca and London 


\section{For my mother, Loula Martin Woodcock}

\section{Copyright $\odot 2004$ by Cornell University}

All rights reserved. Except for brief quotations in a review, this book, or parts thereof, must not be reproduced in any form without permission in writing from the publisher. For information, address Cornell University Press, Sage House, 512 East State Street, Ithaca, New York 14850.

First published 2004 by Cornell University Press First printing, Cornell Paperbacks, 2008

Printed in the United States of America

\section{Library of Congress Cataloging-in-Publication Data}

Tentler, Leslie Woodcock.

Catholics and contraception : an American history / Leslie Woodcock Tentler. p. cm. - (Cushwa Center studies of Catholicism in twentieth-century America) Includes bibliographical references and index. ISBN 978-0-8014-4003-8 (cloth : alk. paper) ISBN 978-0-8014-7494-1 (pbk. : alk. paper)

1. Birth control-United States-Religious aspects-Catholic Church

2. Contraception-United States-Religious aspects-Catholic Church.

3. Catholics-United States-History-20th century. I. Title. II. Series. HQ766.3.T44 2004

$241^{\prime} .66-\mathrm{dc} 22$

Cornell University Press strives to use environmentally responsible suppliers and materials to the fullest extent possible in the publishing of its books. Such materials include vegetablebased, low-VOC inks and acid-free papers that are recycled, totally chlorine-free, or partly composed of nonwood fibers. For further information, visit our website at www.cornellpress.cornell.edu.

$\begin{array}{lllllllllll}\text { Cloth printing } & 10 & 9 & 8 & 7 & 6 & 5 & 4 & 3 & 2 & 1\end{array}$

$\begin{array}{lllllllllll}\text { Paperback printing } & 10 & 9 & 8 & 7 & 6 & 5 & 4 & 3 & 2 & 1\end{array}$ 